\title{
„Baranek pieczony nadziewany, buraki, po sztuce kołacza”. Świąteczne obiady bernardynek krakowskich w drugiej połowie XVIII wieku
}

\begin{abstract}
Abstrakt: Artykuł wpisuje się w dynamicznie rozwijający się w ostatnim czasie w Polsce i zagranicą nurt badań nad kulturą kulinarną. Na podstawie ostatniej części księgi rachunkowej bernardynek krakowskich z drugiej połowy XVIII w. dokonano wstępnej analizy świątecznego menu obiadowego, rzadziej kolacyjnego zakonnic w okresie od listopada 1765 do listopada $1766 \mathrm{r}$. Jadłospis był odmienny od posiłków spożywanych w dni powszednie pod względem liczby dań głównych i ich różnorodności. Jak wynika z zestawień, zakonnice przestrzegały postów kościelnych przed Wielkanocą, Bożym Narodzeniem oraz przez cały rok w środy, piątki i soboty. $Z$ przyrządzanych mięs najpopularniejsza była cielęcina i wołowina oraz drób, z ryb - szczupaki. Z produktów mącznych najczęściej jedzono kaszę, zaś z zup rosół. Bernardynki spożywały też jarzyny i owoce krajowe. Spośród słodkości w badanym źródle najczęściej wymieniono pierniki. Do świątecznych obiadów serwowano wino oraz wódkę; brak informacji o piwie.
\end{abstract}

Abstract: This article is part of a research trend that is currently developing dynamically in Poland and abroad: studies on culinary culture. On the basis of the last part of the account book of the Kraków Bernardine Nuns from the second half of the 18th century, the author conducted a preliminary analysis of the nuns' festive dinner (and more rarely supper) menus from November 1765 to November 1766. The menus differed from weekday meals in terms of the number of main courses and their variety. According to the lists, the nuns observed church fasts before Easter and Christmas, and throughout the year on Wednesdays, Fridays, and Saturdays. The most popular meats were veal and beef, poultry, and fish (pike). As for flour-based products, groats were most frequently consumed, while the most popular soup was broth. The Bernardines also ate vegetables and domestic fruit. Among sweets, gingerbread is the most commonly mentioned in the discussed written record. Wine and vodka were served with festive dinners; there is no information about beer.

Słowa kluczowe: nowożytność, monastycyzm, kultura kulinarna, wyżywienie, bernardynki, Kraków

Key words: modernity, monasticism, culinary culture, nutrition, Bernardine nuns, Kraków

Wśród klasztornych ksiąg rachunkowych, które od lat są przedmiotem moich zainteresowań, na szczególną uwagę zasługuje rękopis z klasztoru Bernardynek przy kościele św. Józefa w Krakowie. Zawiera on nie tylko cenne wiadomości o rzeczach i cenach, ale również bogate informacje dotyczące funkcjonowania tej klauzurowej wspólnoty. Choć został spisany w drugiej połowie XVIII w., czyli w okresie, z którego pochodzi większość zachowanej w klasztorach dokumentacji rachunkowej², to jednak jego wartość jest nie do przecenienia. Obejmuje lata

${ }^{1}$ Cyt. za: ABern.Kr., sygn. 99, Rachunki, s. 158, menu z Niedzieli Wielkanocnej.

2 Źródła rachunkowe znajdują się m.in. w Archiwum Narodowym w Krakowie, Bibliotece Jagiellońskiej i Archiwum Archidiecezjalnym w Gnieźnie, Dochody i wydatki. 2002-2004; Gronowski T.M. 2007, s. 42-43; Przybyłowicz O.M. 2013, s. 101-102; Przybyłowicz O.M. 2019, s. 320 i n. 
1762-1766 i jest najstarszym tego typu źródłem krakowskiego konwentu³. Jego unikatowość polega na wydzieleniu w nim ponad 10 kategorii wydatków, nie tylko na produkty żywnościowe, lecz także np. na prawo oraz myto dla czeladzi. Przede wszystkim uwagę zwraca jednak ostatnie 15 stron $^{4}$, na których znalazły się informacje o jednorocznym, codziennym menu, głównie obiadowym (kolacje nie są wspominane codziennie), sióstr III Zakonu Regularnego św. Franciszka. Nagłówek tej części rękopisu brzmi: „Dnia 8 Novembra R. 1765 w dzień oktawy W. Świętych od elekcyjej dla pamięci wyrozumienia expensy kładą się tu wszystkie obiady”. Zapisy prowadzone były ręką jednej z sióstr (świadczą o tym żeńskie formy orzeczeń) przez rok, do 15 listopada $1766 \mathrm{r}$.

Przełożoną wspólnoty, założonej 12 sierpnia 1646 r. przez Teresę Zadzikównę, siostrę nieżyjącego już wówczas biskupa krakowskiego Jakuba Zadzika, była w omawianym okresie Eleonora Gołuchowska ${ }^{5}$. W rękopisie poinformowano zresztą o jej godności, rozpoczynając rejestr wydatków. Gołuchowska, córka chorążego wiślickiego Krzysztofa, była w historii konwentu zakonnicą wyjątkową — sprawowała urząd przełożonej z przerwami przez blisko 30 lat. Mimo to, o jej działalności wiadomo ze źródeł stosunkowo niewiele. Habit przyjęła w lutym 1737 r. jako piętnastolatka, a już dziesięć lat później została mistrzynią nowicjatu i sprawowała ten urząd przed kilka lat (do 1756 r., choć nie ciągle) ${ }^{6}$. Przełożoną została po raz pierwszy w roku 1759, pełniąc tę funkcję z przerwami przez 11 kadencji; ostatni raz w 1797 r. do śmierci (17 czerwca 1800 r.) $)^{7}$.

Zachowane źródło pochodzi z okresu jej trzeciej kadencji, rozpoczętej właśnie 8 listopada 1765 r. Rękopis nie został nigdy poddany analizie i był wykorzystywany sporadycznie przed dwójkę badaczy. Dane tyczące wybranych grup wydatków przytaczał na kartach jedynej monografii klasztoru Romuald Gustaw ${ }^{8}$. Ostatnie karty rękopisu posłużyły też Małgorzacie Borkowskiej do zilustrowania codziennego pożywienia zakonnic w monografii o realiach życia klasztornego. Cytat przytoczony w pracy M. Borkowskiej może wprowadzać w błąd, gdyż informacja dotyczy posiłku świątecznego (niedziela Zapustna), zatem bardziej wykwintnego, nie zaś serwowanego w zwykłym dniu?.

W niniejszym artykule prezentuję menu obiadów świątecznych. Dokładna analiza całości tego unikatowego źródła będzie tematem kolejnych opracowań, o znacznie większej objętości ${ }^{10}$. Świąteczne jadłospisy dostarczają najwięcej informacji o potrawach nietypowych, których w pozostałe dni tygodnia nie serwowano bernardynkom, bądź podawano bardzo rzadko. Obiady świąteczne to te, które wydawano w niedziele oraz w najważniejsze święta kalen-

${ }^{3}$ ABern.Kr., Rachunki. Paginacja współczesna ołówkiem. Pierwsza księga o charakterze rachunkowym zawiera dane wyłącznie o pewnej grupie przychodów; to rejestr fundacji, posagów i wyderkafów z lat 1645-1658, ABern.Kr., sygn. 14.

${ }^{4}$ W kategorii żywności są: Regestr mięsny, Regestr rybny, Regestr jarzyny, Regestr chleba białego, Regestr oleju, Regestr korzenia (pisane od 7 sierpnia 1762 r.) oraz Regestr wina (od 1762 bez podania miesiąca przy pierwszym wpisie, do listopada 1765 r.), Rejestr piwa (od 19 października 1762 do stycznia 1766 r.). Inne kategorie to: Regestr myta czeladzi, Rejestr prawa (tylko dwie pozycje), Regestr świec, Regestr reparacyj, Regestr drew, Regestr elemozyny, Rejestr przychodów od świeckich panien.

5 Gustaw R., Sitnik A.K. 2013, s. 42-43.

${ }^{6}$ Gustaw R., Sitnik A.K. 2013, s. 64-65; por. też Borkowska M. 2005, s. 220. Tam błędnie podane kadencje E. Gołuchowskiej jako przełożonej, w tym brak informacji o tej trzeciej, sprawowanej w latach 1765-1768.

${ }^{7}$ Gustaw R., Sitnik A.K. 2013, s. 221.

${ }^{8}$ Gustaw R., Sitnik A.K. 2013. Pierwsze wydanie w Krakowie w 1947 r.

9 W publikacji wiadomości te zamieszczono ze złą datą roczną (1675 r.) oraz z błędnymi odczytami: chleb szary, a w źródle „,chleb rżany”; kasza jaglana na sypko, a w źródle „kasza tajona jaglana”; kapusta w szczapy, a w źródle „kapusta w szczepy”; płatki łomane, a w źródle „placki łomane”; bulszruki, a w źródle „bulsztuki”, Borkowska M. 1997, s. 144.

${ }_{10}$ W nich zaprezentuję kuchnię klasztorną bernardynek na tle ówczesnej, staropolskiej kultury kulinarnej, korzystając m.in. z wydawnictw w serii Monumenta Poloniae Culinaria. 
darza kościelnego, w tym obchodzone uroczyście w III Zakonie św. Franciszka od Pokuty. Ta druga kategoria obejmuje: Wielkanoc, Boże Narodzenie, Trzech Króli, Wniebowstąpienie, Zesłanie Ducha Św., Boże Ciało, święta maryjne - Oczyszczenia (2 lutego), Zwiastowania (7 kwietnia), Narodzenia (8 września) i Niepokalanego Poczęcia Najświętszej Marii Panny (8 grudnia), a także świętych — Franciszka (4 października), Antoniego (13 czerwca), Bernardyna (20 maja), Klary (12 sierpnia), Elżbiety (19 listopada) i Józefa (19 marca), jak również Opieki św. Józefa (20 kwietnia), gdyż takie wezwanie nosił kościół bernardynek.

Badania nad kulturą kulinarną w Polsce przeżywają w ostatniej dekadzie rozkwit, przede wszystkim dzięki działalności edytorskiej grona badaczy skupionego wokół Jarosława Dumanowskiego ${ }^{11}$. Problematyka konsumpcji była jednak podejmowana już w latach sześćdziesiątych XX w., w nawiązaniu do badań szkoły „Annales”, przede wszystkim przez Marię Dembińską $^{12}$. O kuchni klasztornej w dobie staropolskiej wiadomo stosunkowo niewiele, choć źródeł z epoki nowożytnej jest znacznie więcej w porównaniu do źródeł średniowiecznych ${ }^{13}$. W odniesieniu do żeńskich konwentów tematykę tę nakreśliła barwnie, ale zaledwie na kilku stronach monografii, M. Borkowska ${ }^{14}$. W rozważaniach autorka nie wyszła jednak poza krąg kilkunastu „smakowitych” cytatów pochodzących z kronik, pamiętników i rachunków klasztornych różnych zgromadzeń. Szczegółową analizę pożywienia benedyktynek sandomierskich, przede wszystkim produktów nabywanych, ale też tych pochodzących z produkcji rolnej klasztoru, przeprowadziła Anna Szylar. Uczyniła to na podstawie dostępnych ksiąg rachunkowych i kroniki, co pozwoliło jej na określenie procentowego udziału wydatków na poszczególne kategorie żywności w dwóch okresach: 1750-1759 i 1806-1816 ${ }^{15}$. Ten pierwszy stanowić będzie dla mnie istotne tło porównawcze. Rachunki wykorzystywała w swoich badaniach także Patrycja Gąsiorowska, pisząc o kuchni i infirmerii klarysek krakowskich ${ }^{16}$. Autorkę bardziej jednak interesowały sprawy organizacji i funkcjonowania kuchni, niż samego menu i nabywanych produktów. Wymieniła też kilkanaście potraw, które pojawiały się na stole zakonnic w dni świąteczne. Jedynym artykułem poruszającym problematykę jadłospisu jest krótki, czterostronicowy tekst Jerzego Rajmana, odnoszący się do pożywienia norbertanek na Zwierzyńcu, przygotowany na podstawie rachunków, zachowanych w archiwum tamtejszego konwentu. Autor nie podał nawet tytułu rękopisu, nie dokonał też charakterystyki omawianego źródła. Wymienił kupowane artykuły oraz kilka zestawów potraw jedzonych przez siostry w dni zwyczajne, świąteczne i postne. Opisując menu dzienne (nie podano jednak, czy obiadowe, czy kolacyjne), posługiwał się nieprecyzyjnymi kategoriami: najczęściej, często, chętnie, co de facto uniemożliwia badania porównawcze ${ }^{17}$.

Wobec powyższych uwag unikatowe informacje z rękopisu bernardynek umożliwiają poszerzenie wiedzy o klasztornej kuchni i stole w drugiej połowie XVIII stulecia. Uwzględniony rękopis ukazuje istotny fragment codzienności życia za klauzurą — kulturę kulinarną klasztoru w epoce staropolskiej oraz wewnętrzną organizację wspólnoty.

Rozważania rozpocznę od stwierdzenia dość oczywistego, że w kuchni bernardynek, co znalazło odzwierciedlenie w menu, przestrzegano postów kościelnych. Potraw mięsnych nie jedzono przez cały rok trzy dni w tygodniu (w środy, piątki i soboty), nawet wówczas, gdy w którymś z tych dni przypadało święto kościelne lub zakonne. Post zachowywano przed Wielką Nocą oraz

11 Dumanowski J. 2014, s. 527-540.

12 Dembińska M. 1963a, s. 7-15; Dembińska M. 1963b; Dembińska M. 1973, s. 39 i n.; Dembińska M. 1985, s. 367-381.

13 Rajman J. 2001, s. 183 i n.; Wyrwa A. M. 2004, s. 51-113.

14 Borkowska M. 1997, rozdz. 19: Co panny jadty i pity, s. 139-146.

15 Szylar A. 2004, s. 32-38; Szylar A. 2005, s. 189-224.

${ }^{16}$ Gąsiorowska P. 2010, s. 394-406.

17 Rajman J. 2010, s. 407-411. 
Bożym Narodzeniem, rozpoczynając go w środę po św. Marcinie (11 listopada). W roku 1765 ten dzień wypadał 13 listopada: „[...] z postem przywitanie dusz siostrzeńskich”18. Znikały wówczas ze stołu mięsiwa, a główne dania obiadowe stanowiły ryby ${ }^{19}$. Różnice w jadłospisie postnym i niepostnym, nie tylko w dni świąteczne, są znaczące. W niedzielę Zapustną (10 listopada) na stole bernardynek postawiono: rosół z kur, po ćwierci kury i gęsi pieczonej z jabłkami, cielęcinę w żółtym sosie z kluskami, pieczeń krzyżową z limonią i oliwkami, kapustę w szczepy z wieprzowiną oraz bulsztuki nadziewane w sosie migdałowym ${ }^{20}$. Było wino oraz wódka dana „,do refektarza” dla wszystkich zakonnic. Kwartę wina i wódki otrzymał również spowiednik wspólnoty.

W pierwszą niedzielę postu (17 listopada) menu było już zdecydowanie odmienne: szara polewka z drobną kaszką, karaski w szarym sosie, kasza jaglana i jarzyna ${ }^{21}$. Znacznie bardziej wystawny obiad zjadły zakonnice dwa dni później, we wtorek, w święto Elżbiety — tercjarki franciszkańskiej, siostry króla Węgier Beli IV oraz ciotki Kingi i Jolenty (klarysek, fundatorek klasztorów w Starym Sączu i Gnieźnie). Elżbietę w zakonie bernardyńskim otaczano wielką czcią i uznawano za szczególną patronkę. Z tej okazji podano: szczupaki w żółtym sosie, karpie po węgiersku, kaszę, domowy susz, a z napojów — wino i wódkę siostrom do refektarza. Te same trunki otrzymali księża. Przekazano je też do furty „dla gościny”22.

Najbardziej wystawne i obfite obiady, z liczbą dań przekraczającą pięć, serwowano w święta Bożego Narodzenia i Wielkiej Nocy. W Wigilię 1765 r. zjedzono: ryby w żółtym sosie, szczupaki w białym sosie, karpie po węgiersku, drobną kaszę, jarzyny, śliwki, pierniczki, po sztuce strucli (zapewne dla każdej zakonnicy); dzielono się też opłatkami. Wódka podana została do refektarza, zaś ojcu spowiednikowi ofiarowano kwartę wina ${ }^{23} .25$ grudnia był rosół z perłową kaszą, a do tego kury, cielęcina w żółtym sosie z makaronem, pieczenie cielęce z podlewą i buraki. W czasie tego posiłku każda bernardynka dostała również struclę. Częstowano też pierniczkami, winem i wódką. Wino otrzymali także spowiednik, lektor oraz pewne osoby asystujące (zapewne do mszy) i laicy. Dano je także do furty, zaś garniec miodu przygotowano dla ojca kustosza „po kolędziu”24. 26 grudnia, w dniu św. Szczepana, były ponownie: rosół i kury do niego, cielęcina w żółtym sosie z kluseczkami, pieczenie krzyżowe z oliwkami, ozory do imbiru, bulsztuki, gęsi zapiekane z jabłkami, kapusta w szczepy z wieprzowiną. Zaserwowano łącznie osiem dań głównych — najwięcej w rocznym menu obiadowym — nie licząc słodkości (pierniczki i strucla) oraz alkoholu — wódka i wino dla sióstr, butelka wina dla spowiednika ${ }^{25}$.

Kolejnym obiadem, imponującym pod względem liczby potraw, był posiłek wydany 9 lutego 1766 r., w ostatnią niedzielę przed czterdziestodniowym postem. Zaserwowano wówczas: rosół z kurami, cielęcinę w żółtym sosie z kluskami, duszone pieczenie, gęsi pieczone z cebulą, buraki z wieprzowiną, ponownie bulsztuki (bez informacji o nadzieniu) oraz pierniki, a także wino i wódkę ${ }^{26}$. Wyjątkowo obfity obiad przygotowano też w niedzielę 23 lutego, już w trakcie postu. Wtedy to przypadało wspomnienie św. Eleonory, czyli imieniny matki przełożonej. Do jedzenia była polewka migdałowa z ryżem, szczupaki w szarym sosie z kaparami i oliwkami,

${ }^{18}$ ABern.Kr., Rachunki, s. 151.

19 Kracik J. 1985, s. 65 i n.

${ }^{20}$ ABern.Kr., Rachunki, s. 151. Nie udało mi się zidentyfikować, czym były bulsztuki. Jak wynika z analizy zapisów, było to danie specjalne, świąteczne, mięsne. Prof. Jarosław Dumanowski i dr Patrycja Gąsiorowska sugerują niemiecki źródłosłów potrawy (der Bulle - wół). P. Gąsiorowska odnalazła tę potrawę również w rachunkach klarysek krakowskich z pierwszej połowy XVIII stulecia. Dziękuję obojgu badaczom za wszystkie uwagi. Być może wyjaśnienie znaczenia tego terminu umożliwią dalsze badania nad rękopisami wspólnot krakowskich.

${ }^{21}$ ABern.Kr., Rachunki, s. 151.

${ }^{22}$ ABern.Kr., Rachunki, s. 152.

${ }^{23}$ ABern.Kr., Rachunki, s. 154.

${ }^{24}$ ABern.Kr., Rachunki. s. 154.

${ }^{25}$ ABern.Kr., Rachunki, s. 154.

${ }^{26}$ ABern.Kr., Rachunki, s. 156. 
wyzina, czyli bieługa ${ }^{27}$ z podlewą, kasza drobna z rodzynkami i cukrem, ciasto oliwne, pierniczki, gruszki strugane, oraz trunki — wódka i wino dla sióstr oraz księdza (najpewniej tym mianem określono kapelana ${ }^{28}$. Następnym, wyróżniającym się obfitością w realiach postu, był posiłek spożyty 19 marca (środa), w św. Józefa. Wspólnocie przygotowano ucztę rybną: ,,szczupaki ze wszytką należytą zaprawą, żółto okonie, szaro szczupaki słone z podlewą i migdałami, karpie czarno, wyzina do imbieru, stokwisz ${ }^{29}$, śliwki, kasza drobna, kapusta z ikrami”, a do tego pierniki, placki, wódkę i wino dla zakonnic oraz duchownych: spowiednika i „dwóch księży co zakrystyjej pilnowali [...] dla księży gościnnych u forty"30. Dzień patrona kościoła traktowano jako szczególne święto nie tylko u bernardynek, ale też w innych wspólnotach, np. u krakowskich klarysek w dniu św. Andrzeja obiad był wystawny, chociaż także wypadał w poście ${ }^{31}$.

Wielka Sobota była przedsmakiem obfitości czekającej zgromadzenie po długim poście. Podano wówczas zupę gramatkę słodzoną, ryby smażone, kapustę i biały groch, szczupaczki w białym sosie, ,grzaneczki z makiem”, wino i wódkę. W Wielką Niedzielę były: jaja święcone, szynka, rosół z kur, barszcz zabielany „,po trzy jaja w niem przypiekane”, cielęcina w żółtym sosie, baranek pieczony nadziewany, buraki, po sztuce kołacza, pierniki oraz wino i wódka dla sióstr, a także butelka wina dla spowiednika ${ }^{32}$. W świąteczny poniedziałek na stole postawiono: polewkę winną, ryby w białym sosie, pierogi z twarogiem, jaja pieczone, kaszę w mleku drobną, kołacz twarożny (po sztuce dla każdej siostry), jak również pierniki, wódkę i wino dla zakonnic oraz wino dla spowiednika ${ }^{33}$. W pierwszą niedzielę poświąteczną (Przewodnią) także zjedzono specjalny obiad, w tym: szynkę, sztukę mięsa z białym grochem ${ }^{34}$, cielęcinę w żółtym sosie z makaronem, ,pieczenie cielęce z saporem" ${ }^{35}$ oraz buraki ${ }^{36}$. Wódkę podano do stołu tylko „ex Matkom”, czyli byłym przełożonym wspólnoty, zaś wino i wódkę księdzu spowiednikowi. Menu obiadowe było bogatsze w porównaniu do zwykłej niedzieli również 20 kwietnia, gdy przypadło (w trzecią niedzielę po Wielkanocy) święto Opieki św. Józefa. Wśród dań znalazły się: cielęcina do rosołu, sztuka mięsa z chrzanem, ozory, pieczenie cielęce, jarzyna oraz wódka i wino dla sióstr, a także wino dla księdza, kaznodziei, spowiednika i do furty ${ }^{37}$.

Wyjątkowy pod względem posiłków był maj, który obfitował w liczne święta. 8 maja, w czwartek, w dzień Wniebowstąpienia bernardynki otrzymały: sztukę mięsa z białym grochem, cielęcinę na frykasik w białym sosie z siekaniem, ozory, „dychy cielęce z saporem”38, jarzynę oraz wódkę i wino, to ostatnie także przeznaczono oddzielnie dla spowiednika ${ }^{39} .18$ maja, tj. w Zesłanie Ducha Św., na obiad przygotowano: szynkę, kury do rosołu (po ćwierci), cielęcinę w żółtym sosie z kluskami, prosięta nadziewane, buraki, pierniki, wódkę oraz wino, które

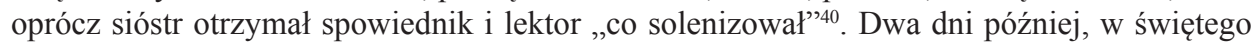

${ }^{27}$ Ryba z rodziny jesiotrowatych, popularna na stołach wyższych warstw w XVIII w., sprowadzana szczególnie do Lwowa i Krakowa z Morza Czarnego, Kaspijskiego, Azowskiego, Staropolskie przepisy. 2017, s. 114.

28 ABern.Kr., Rachunki, s. 157.

${ }_{29}$ Suszony, solony dorsz, popularne źródło białka od średniowiecza, Staropolskie przepisy. 2017, s. 325.

30 ABern.Kr., Rachunki, s. 158.

31 Gąsiorowska P. 2010, s. 400: szczupaki, polewka migdałowa, kasza z cynamonem na obiad. Niestety autorka nie podała roku, którego dotyczyły dane, a korzystała z trzech ksiąg rachunkowych z XVIII stulecia.

32 ABern.Kr., Rachunki, s. 158.

33 ABern.Kr., Rachunki, s. 158.

34 Była to potrawa z gotowanej wołowiny, Księga szafarska. 2013, s. 57.

35 Od łac. smak — w kuchni staropolskiej to specjalny dodatek w postaci sosu, polewy, zaprawy, Staropolskie przepisy. 2017, s. 324. Wydaje się jednak, że u bernardynek nie był to sos, bo te wymieniano osobno.

36 ABern.Kr., Rachunki, s. 159.

37 ABern.Kr., Rachunki, s. 159.

38 Dych, czyli udziec, Staropolskie przepisy. 2017, s. 96.

39 ABern.Kr., Rachunki, s. 160.

${ }^{40}$ ABern.Kr., Rachunki, s. 160. 
Bernardyna, patrona zgromadzenia, menu było jeszcze bardziej okazałe: cielęcina do rosołu, „prosięta na szaro”, pieczenie cielęce z sałatą, kapusta, pierniki oraz wódka i wino, które otrzymali także księża: zakonnik określony mianem ojca, spowiednik, lektor, zaś asystujący księża dostali wódkę i miód ${ }^{41}$. 29 maja — w Boże Ciało obiad składał się z czterech dań mięsnych: sztuka mięsa, cielęcina, ozory oraz dychy cielęce, do tego sałata i jarzyny, a na deser pierniki, zaś do picia wino (także dla księży) oraz wódka do refektarza ${ }^{42} .13$ czerwca, w piątek w św. Antoniego, nie było mięs, ale na stole postawiono inne, niecodzienne potrawy: szczupaki w sosie, smażone pierożki słodzone makiem, drobną kaszę, śliwki suche; było też wino dla sióstr ${ }^{43}$. Niedziela 27 lipca była wyjątkowym dniem dla konwentu, gdyż świętowano — jak napisała autorka rachunków - „wykupienie się za siostrę Krystynę"44. Sprawa dotyczyła najprawdopodobniej uregulowania należności wobec rodziny zakonnicy ${ }^{45}$. Na obiad zaserwowano: rosół z makaronem, a do niego gęsi, frykasik cielęcy z siekaniem i kaparami, pieczenie krzyżowe duszone z oliwkami i cytryną, kurczęta pieczone z sałatą, poza tym marchew, ,agryst na wety” i sucharki ${ }^{46}$. Była też wódka dla „ex Matek” oraz wino dla sióstr i kapelana.

Kolejne, wyszukane dania zagościły na stole bernardynek 15 sierpnia (piątek). Były to: raki i ryby w białym sosie (bez wymieniania gatunków), potaź, czyli bulion (u bernardynek wyłącznie warzywny $)^{47}$, kaszka drobna z cukrem, karczochy, gruszki strugane, na wety zaś jabłka, agrest i gruszki, ponadto pierniki ${ }^{48}$. Obfity posiłek popijano winem i wódką. W następne święto maryjne - 8 września (poniedziałek) obiad składał się ze: szczupaków w żółtym sosie z rodzynkami, pierogów leniwych, kaszy w mleku, jarzyn, a na deser gruszek struganych i pierników; podano też wino siostrom i księdzu kapelanowi, który dostał też wódkę ${ }^{49}$.

Specjalne menu przygotowano oczywiście w dniu założyciela zakonu — św. Franciszka z Asyżu (4 października). Składały się nań: „żółto szczupaki z dobrą zaprawą”, szczupaki w białym sosie, karpie po węgiersku, kasza drobna, kapusta, groch i karczochy, ponownie gruszki strugane i wety, pierniki, wódka oraz wino dla zakonnic i księdza kapelana ${ }^{50}$. Wyjątkowo obfity i wykwintny obiad zaserwowano w ostatnią niedzielę przed postem bożonarodzeniowym. Przyrządzono wówczas: sztukę mięsa do rosołu, ozory, pieczenie wieprzowe, sarnę z sosem pieczoną i śpikowaną ${ }^{51}$ oraz kapustę słodką ${ }^{52}$, poza tym zaserwowano wino i wódkę dla księdza kapelana i dla „ex Matek”.

Przechodząc do statystycznego ujęcia potraw w dni świąteczne, można stwierdzić, że taki standardowy posiłek składał się z czterech dań. Notowano wówczas w źródle, że to „obiad zwyczajny na czworo", ale nie podając, o jakie potrawy chodziło. Taki zapis w badanym okresie pojawił się 24 razy. Obiady z większą liczbą dań odnotowano w święta 26 razy (cztery

41 ABern.Kr., Rachunki, s. 160.

${ }^{42}$ ABern.Kr., Rachunki, s. 160.

43 ABern.Kr., Rachunki, s. 162.

44 Na podstawie katalogu zakonnic, sporządzonego przez R. Gustawa, siostra Krystyna to najprawdopodobniej Krystyna Gładyszewska (imię świeckie Salomea), która wstąpiła do konwentu w roku 1759. Nie było wówczas innej siostry Krystyny. Przed wstąpieniem za klauzurę imię to miały: Eleonora Gołuchowska oraz Krystyna Królikowska (obłóczyny 1756, w zakonie Teofila) (Gustaw R., Sitnik A.K. 2013, s. 222; także Borkowska M. 2005, s. 222). Autorka rękopisu używała imion zakonnych, a nie świeckich.

45 Borkowska M. 1996, s. 55-63; Szylar A. 2013, s. 449-450 — o rozliczeniach z rodzinami.

46 ABern.Kr., Rachunki, s. 163.

47 Potaź mógł zawierać kawałki chleba, jarzyny lub mięsa. W analizowanym źródle występuje rzadziej niż rosół i tylko w okresie postu, a więc był bezmięsny. Moim zdaniem nie można utożsamiać tych dwóch zup, co dopuszcza J. Dumanowski, Staropolskie przepisy. 2017, s. 324.

48 ABern.Kr., Rachunki, s. 164.

49 ABern.Kr., Rachunki, s. 164.

${ }^{50}$ ABern.Kr., Rachunki, s. 165.

51 Śpikowanie to umieszczanie w mięsie dziczyzny lub dzikiego ptactwa słupków wędzonej, tłustej słoniny, Staropolskie przepisy. 2017, s. 325.

52 ABern.Kr., Rachunki, s. 166. 
święta wypadały w niedziele). Brak danych o wielkości porcji uniemożliwia ustalenie, ile jedzenia przypadało na poszczególne zakonnice. Zaledwie kilka razy podano konkretne informacje — dla każdej siostry przygotowano po ćwierć kury do rosołu lub ćwierć gęsi oraz po jednym kołaczu bądź strucli. Niewykluczone, że wydzielano te same porcje kapelanowi i innym księżom uczestniczącym w obiadach bernardynek.

Ryby królowały na stole świątecznym w dni postne, a mięso w pozostałe ${ }^{53}$. Spośród ryb najbardziej wykwintną potrawą, serwowaną głównie w najważniejsze święta kościelne, były szczupaki przyrządzano na ,żółto, biało lub z podlewą i migdałami” (w sumie 18 razy) ${ }^{54}$. Ceniono też karpia (5 razy), określanego najczęściej jako „po węgiersku” (4 razy) ${ }^{55}$. Ogólne sformułowanie „ryby” zarejestrowano 10 razy, zaś wspomnianą wyżej wyzinę — czterokrotnie. Tylko raz zostały wymienione karaski, okonie, stokwisz oraz ikra (ikrowe kluski) i raki ${ }^{56}$. W porównaniu do zakupów ryb u benedyktynek sandomierskich, u bernardynek krakowskich brak w menu obiadowym ryb beczkowanych — solonych i suszonych, w tym śledzi ${ }^{57}$. Natomiast u klarysek sądeckich na początku XVII stulecia najczęściej kupowanym gatunkiem ryb były łososie, których na stole bernardynek w XVIII w. w ogóle nie było ${ }^{58}$.

$\mathrm{Z}$ mięs najpopularniejsza była cielęcina (w badanym okresie podawana 13 razy), także w postaci pieczeni ( 7 razy) oraz dych ( 2 razy). Wołowinę serwowano jako pieczeń krzyżową ( 3 razy), sztuki mięsa (13 razy), ozory ( 9 razy) i być może bulsztuki (4 razy) oraz flaki (4 razy) ${ }^{59}$. Pieczenie duszone, krzyżowe i wieprzowe (dwukrotnie) odnotowano wówczas 20 razy. Siostry jadały też wieprzowinę (5 razy). Prosięta nadziewane i pieczone spożywano w dniu Zesłania Ducha Św. i św. Bernardyna ${ }^{60}$. Dwukrotnie w ciągu roku zaserwowano nieokreślony gatunek mięsa, zaś trzy razy szynkę $e^{61}$. Z drobiu najczęściej jedzono kury podawane do rosołu (8 razy) oraz gęsi z jabłkami (5 razy). Tylko raz wzmiankowano kurczęta — w niedzielę lipcową, gdy świętowano uregulowanie spraw finansowych z rodziną siostry Krystyny. Jeden raz w menu wymieniono też pieczone baranki (na Wielkanoc) oraz sarninę (9 listopada 1766, w niedzielę Zapustną) ${ }^{62}$. To pierwsze danie gościło również w czasie świąt na stole norbertanek na Zwierzyńcu ${ }^{63}$.

Zarówno ryby, jak i mięsa podawano z sosami. Przygotowywano sosy: przeważnie żółty (17 razy, w jednym przypadku z dodatkiem wina i cynamonu), niemal równie często biały (16 razy), sporadycznie zaś szary (4 razy), albo czarny (1 raz na św. Józefa, były w nim karpie) i migdałowy (w nim bulsztuki w niedzielę Zapustną 1765 r.) ${ }^{64}$.

Z produktów mącznych, które stanowiły nieodzowny składnik menu zakonnic, najczęściej spożywano kasze (które wymieniono 22 razy). Dominowała kasza drobna (11 razy) jedzona

53 Szylar A. 2005, s. 191. Na mięso benedyktynki w latach 1750-1759 wydawały aż 39,98\% wszystkich środków przeznaczanych na pożywienie, zaś na ryby 17,93\%, choć faktyczne proporcje spożycia mogły przedstawiać się inaczej, bo rachunki wydatków nie uwzględniają dostaw z folwarków, zarówno zwierząt, jak i ryb, Gąsiorowska P. 2010, s. 398.

${ }^{54}$ ABern.Kr., Rachunki, s. 151-166.

55 ABern.Kr., Rachunki, s. 152, 154, 165. P. Gąsiorowska wymieniła śledzie, szczupaki i karpie jako najpopularniejsze ryby na stole klarysek, Gąsiorowska P. 2010, s. 399.

${ }^{56}$ ABern.Kr., Rachunki, s. 158, 164.

57 Szylar A. 2005, s. 193.

58 Przybyłowicz O.M. 2011, s. 205.

59 Wołowina i cielęcina były najpopularniejszym i najczęściej kupowanym mięsem przez benedyktynki w Sandomierzu (Szylar A. 2005, s. 191) oraz przez starosądeckie klaryski w początkach XVII stulecia (Przybyłowicz O.M. 2011, s. 204).

${ }^{60}$ ABern.Kr., Rachunki, s. 160-161.

${ }^{61}$ Szynka w okresie Wielkanocy oraz w Zesłanie Ducha Św., ABern.Kr., Rachunki, s. 158-160.

62 ABern.Kr., Rachunki, s. 158, 166.

${ }^{63}$ Rajman J. 2010, s. 411.

${ }^{64}$ ABern.Kr., Rachunki, s. 151-166. 
w święta maryjne, patronów zakonnych i na Wielkanoc. Serwowano też tę najdroższą, znaną m.in. ze stołu królewskiego - jaglaną ( 7 razy $)^{65}$. Wymieniono też perłową i kaszę nieokreśloną gatunkowo (po 2 razy). Bernardynki jadały też kluski (3 razy), makaron ( 3 razy), różne pierożki ( 5 razy, w tym: z jabłkami, twarogiem, z powidłami smażone, na słodko), leniwe (1 raz, 8 września ${ }^{66}$ oraz ryż (tylko w dniu św. Eleonory). Na Wigilię zapewniono opłatki, zaś grzaneczki zaserwowano w Wielką Sobotę ${ }^{67}$. Tylko jeden raz (w niedzielę Zapustną 1765 r.) podano chleb.

Wśród dań obiadowych niezwykle mało było nabiału — mleko dwa razy do kaszy (m.in. na Wielkanoc) oraz jaja przypiekane w Wielką Niedzielę i w Wielki Poniedziałek ${ }^{68}$. Jaj używano do wypieków i jedzono zapewne w różnych postaciach w dni nieświąteczne, także na kolacje, a posiłki te często określano w źródle mianem „zwyczajnych”.

Najczęściej podawaną zupą był rosół (13 razy), natomiast w postne dni potaź (4 razy) oraz szara polewka (1 raz) ${ }^{69}$. Bardziej wykwintne były polewki: winna (wymieniona dwukrotnie — w Poniedziałek Wielkanocny i w dniu Zwiastowania NMP), barszcz zabielany (przyrządzony 2 razy — na Wielkanoc i w Zaduszki) i polewka migdałowa (23 lutego, tj. w św. Eleonory) ${ }^{70}$. Polewki takie, m.in. migdałowa i winna, gościły także na świątecznym stole klarysek krakowskich w drugiej połowie XVIII stulecia ${ }^{71}$.

Warzyw podawano całkiem sporo i bardziej różnorodnych niż np. na stole królewskim Jana III Sobieskiego, na którym dominowała cebula (wymieniona 140 razy w źródle obejmującym zapisy ze 172 dni) ${ }^{72}$. Bernardynki miały do wyboru: jarzynę (17 razy), groch (10 razy, w tym 8 razy określony jako biały), kapustę i pasternak ${ }^{73}$ (po 8 razy), buraki (5 razy), sałatę i susz (po 3 razy), marchew (2 razy), cebulę i rzepę (po razie). Podobny zestaw jarzyn wzmiankowany był w jadłospisie norbertanek na Zwierzyńcu ${ }^{74}$. Natomiast wyłącznie w źródle bernardynek odnotowano wykwintne karczochy (15 sierpnia i 4 października — w św. Franciszka) oraz kapary (23 lutego — św. Eleonory i 27 lipca) jako dodatki do głównych dań rybnych bądź mięsnych ${ }^{75}$.

Wśród przypraw i dodatków do mięs, ryb i sosów wymieniono: oliwki (4 razy), chrzan (2 razy), imbir (2 razy) i cynamon (1 raz). Słodkimi dodatkami do potraw były: mak (3 razy: do kaszy, do grzaneczek, do pierożków), cukier (2 razy), rodzynki (2 razy) oraz migdały i powidła (wymienione jeden raz) ${ }^{76}$. W daniach bernardynek nie stosowano innych korzeni, używanych do potraw serwowanych na stołach klasztornych, magnackich, a nawet królewskich: szafranu, goździków i kwiatu muszkatu, choć niewykluczone, że ich „odkrycie” umożliwi dopiero dokładniejsza analiza wydatków z księgi rachunkowej ${ }^{77}$.

Owoce uzupełniały dania mięsne (jabłka i śliwki, limonie i cytryny — odnotowane jeden raz) i wety (agrest). Jedzono je także jako deser: gruszki strugane (4 razy) oraz jabłka, śliwki i agrest ${ }^{78}$. Słodkości w menu to ciasta przyrządzane bądź kupowane wyłącznie w święta Bożego Narodzenia i Wielkiej Nocy, w uroczystości maryjne i patronów zakonu oraz kościoła ber-

${ }^{65}$ Księga szafarska. 2013, s. 27.

${ }^{66}$ ABern.Kr., Rachunki, s. 152-162.

${ }^{67}$ ABern.Kr., Rachunki, s. 154, 158.

68 ABern.Kr., Rachunki, s. 158.

${ }^{69}$ Szara polewka w niedzielę Zapustną 1765 r. (ABern.Kr., Rachunki, s. 151). Rosół był też najpopularniejszy u norbertanek (Rajman J. 2010, s. 409).

${ }^{70}$ ABern.Kr., Rachunki, s. 157-159, 166.

${ }^{71}$ Gąsiorowska P. 2010, s. 399.

72 Ponadto po kilkanaście razy w spisie wymienione zostały: pietruszka, rzepa, kapusta, rzadko zaś marchew, pasternak i grzyby, Księga szafarska. 2013, s. 28-29.

$73 \mathrm{Z}$ rodziny selerowatych, o korzeniu podobnym do pietruszki i o słodkawym smaku.

74 Rajman J. 2010, s. 409.

75 ABern.Kr., Rachunki, s. 157, 163-165.

76 ABern.Kr., Rachunki, s. 151-152, 154, 156-159, 162-164.

77 Szylar A. 2005, s. 197; por. też Kramarska-Anyszek K. 1977, s. 96; Gąsiorowska P. 2010, s. 398-399; Przybyłowicz O.M. 2011, s. 206, 209.

${ }_{78}$ ABern.Kr., Rachunki, s. 151, 154-155, 157-158, 162-164. 
nardynek. W źródle najczęściej wspominano o piernikach (18 razy, raz określone jako pierniczki). Były one popularnym, słodkim wyrobem już od XVII stulecia. Z ich wypieku znane były krakowskie klaryski, zaś zakonnice konwentu św. Klary ze Starego Sącza, jak wynika z rachunków z początku XVII w., kupowały miodowniki właśnie w Krakowie ${ }^{79}$. Benedyktynki w Sandomierzu miały własny przepis na ten rodzaj korzennych wypieków ${ }^{80}$. Tylko w okresie Bożego Narodzenia (24-26 grudnia) podawano bernardynkom strucle, podobnie jak klaryskom krakowskim; zaś na Wielkanoc roku 1766 (30-31 marca) specjalnym ciastem były kołacze (jeden określono jako twarożny ${ }^{81}$. W inne dni słodkie wypieki należały do rzadkości: w św. Eleonory było ciasto oliwne, w święto Zwiastowania NMP ciasto „trzygrosznie”, zaś w dniu Niepokalanego Poczęcia NMP po prostu ciasto. Wspomniano też wety (dwukrotnie, z okazji 15 sierpnia i 4 października w św. Franciszka) oraz placki (tylko w św. Józefa) ${ }^{82}$.

W świąteczne i niedzielne obiady na stół bernardynek serwowano wino i wódkę, zarówno dla sióstr, jak i dla księży: kapelana, spowiednika, lektora oraz zaproszonych duchownych, asystujących w liturgii. Podobnie czyniono w dni świąteczne w innych klasztorach, nie tylko krakowskich $^{83}$. Wódkę i wino dla księży — bez określenia miar, a czasami z informacją, iż była to kwarta, pół garnca lub butelka (o czym wspomniano tylko raz) wymieniono w źródle aż 51 razy. Kilka razy zaznaczono, że wino było do mszy świętej. Dziwi natomiast zupełny brak piwa podczas tych odświętnych posiłków u bernardynek. Spożycie tego napoju w epoce staropolskiej, także w klasztorach, było znaczące ${ }^{84}$. Inny trunek - miód zanotowano w rękopisie trzy razy - 15 i 25 grudnia oraz 20 maja, w dniu św. Bernardyna: ,asystecyi przez trzy dni garniec miodu i wódki" " 5 . Wino dla sióstr — dwa bądź trzy garnce - (garniec krakowski to ok. 2,75 litra) odnotowano w źródle 28 razy. Oprócz najważniejszych świąt kościelnych i zakonnych podano je także 1 i 3 listopada (dzień określony jako Zaduszki) 1766 r. oraz w niedziele: Zapustną 1765 r. (10 listopada) i Mięsopustną 1766 r. (26 stycznia) ${ }^{86}$. Wódkę „,do refektarza”, czyli dawaną wszystkim zakonnicom, wzmiankowano 24 razy, zaś „ex Matkom” zaserwowano 35 razy. Kilka razy przy zapisie „wódka ex Matkom” dodano, że chodzi o kwartę, czyli 0,94 litra ${ }^{87}$. W źródle brak informacji o gatunku wódki i zawartości alkoholu (w XVIII w. było to od 17 do 23\%). Jej obecność na stole bernardynek potwierdza osiemnastowieczną tendencję wzrostu spożycia tego alkoholu do posiłków ${ }^{88}$.

Ponieważ R. Gustaw zestawił skład osobowy konwentu, to można pokusić się o szacunkowe obliczenie, ile alkoholu przypadało na zakonnicę, przy teoretycznym założeniu, że wszystkie bernardynki uczestniczyły w obiadach w refektarzu. Można przypuszczać, że ze względu na stan zdrowia lub wiek obiady niektórym siostrom przynoszono do cel. Wspólnota bernardynek w połowie lat sześćdziesiątych XVIII w. składała się z 24 zakonnic $^{89}$. Tak więc przy dwóch garncach wina podawanych do obiadu na jedną siostrę przypadało 0,23 litra, a przy trzech garncach $-0,34$ litra. W 1765 r. w klasztorze były dwie „ex Matki”: Agnieszka Strusówna (†1773) i Franciszka Wiszowata $(† 1777)^{90}$. Być może mianem tym określano także ich zastępczynie — wikarie. W przy-

79 Przybyłowicz O.M. 2011, s. 205.

${ }^{80}$ Gąsiorowska P. 2010, s. 399; Szylar A. 2005, s. 194.

81 ABern.Kr., Rachunki, s. 154, 158; Gąsiorowska P. 2010, s. 399.

82 ABern.Kr., Rachunki, s. 153-154, 157-158, 164-165.

83 Rajman J. 2010, s. 410; zob. też Szylar A. 2005, s. 199; Gąsiorowska P. 2010, s. 400.

${ }^{84}$ Klonder A. 2018, s. 20-40. Piwo było najbardziej popularnym napojem na stole benedyktynek sandomierskich (Szylar A. 2005, s. 199) i klarysek (Gąsiorowska P. 2010, s. 397, 399), a także u norbertanek zwierzynieckich (Kramarska-Anyszek K. 1977, s. 95-96).

${ }^{85}$ ABern.Kr., Rachunki, s. 161.

${ }^{86}$ ABern.Kr., Rachunki, s. 151, 155, 166.

87 Reformę miar przeprowadzono w 1764 r., Kucharz Doskonały. 2012, s. 343.

${ }^{88}$ Klonder A. 2018, s. 32; Więcławski B. 1989, s. 148-149.

${ }^{89}$ Gustaw R., Sitnik A.K. 2013, s. 221-223.

${ }^{90}$ Gustaw R., Sitnik A.K. 2013, s. 210. 
padku podziału wspomnianej porcji wódki na dwie osoby wypadałoby ok. 0,45 litra na osobę, ale przy większej liczbie zakonnic z grona „ex Matek” ilość była odpowiednio mniejsza. O kubku wódki podawanym do posiłku wspomniano też w rękopisie norbertanek na Zwierzyńcu ${ }^{91}$.

Podsumowując powyższe, wstępne rozważania na temat wyżywienia i świątecznego menu obiadowego zakonnic krakowskiego klasztoru III Reguły św. Franciszka od Pokuty, należy podkreślić, że siostry jadały dość urozmaicone posiłki, potraw było sporo, nawet w dniach postnych. Zgodnie z trendami kulinarnymi epoki, dania pozbawione były ostrych przypraw i smakowych kontrastów, które dominowały w kuchni polskiej w XVII w. ${ }^{92}$ Zestaw konsumowanych dań stawia tę krakowską wspólnotę wśród wyższych warstw społecznych Rzeczpospolitej w XVIII stuleciu.

Adres Autorki:

dr Olga Miriam Przybyłowicz

Instytut Archeologii i Etnologii PAN

Al. Solidarności 105

00-140 Warszawa

olgamiriam@interia.pl

http://orcid.org/0000-0003-3422-550X

\section{BIBLIOGRAFIA}

\section{Źródła archiwalne}

ABern.Kr. [Archiwum Bernardynek Krakowskich], Rachunki, sygn. 99 - Księga wydatków klasztoru św. Józefa w Krakowie 1762-1766.

ABern.Kr. [Archiwum Bernardynek Krakowskich], sygn. 14 - Regestr fundacji, posagów i wyderkafów (1645-1773).

\section{Źródła publikowane i opracowania}

Borkowska Małgorzata. 1996. Panny siostry w roli instytucji ustugowej. Czego oczekiwało społeczeństwo od klasztoru żeńskiego w XVII i XVIII wieku, [w:] Klasztor w spoleczeństwie średniowiecznym i nowożytnym, red. M. Derwich, A. Pobóg-Lenartowicz, Wrocław-Opole, s. 55-63.

Borkowska Małgorzata. 1997. Życie codzienne polskich klasztorów żeńskich w XVII-XVIII w., Warszawa.

Borkowska Małgorzata 2005. Leksykon zakonnic polskich epoki przedrozbiorowej, t. 2: Polska Centralna i Poludniowa, Warszawa.

Dembińska Maria. 1963a. Dzienne racje żywnościowe w Europie w IX-XVI wieku, „Studia i Materiały z Historii Kultury Materialnej”, t. 52, nr 1, s. 7-115.

Dembińska Maria. 1963b. Konsumpcja żywnościowa w Polsce średniowiecznej, Wrocław.

Dembińska Maria. 1973. Z badań nad dziennymi racjami żywnościowymi w XIII-XVI w., [w:] Pożywienie ludności wiejskiej, red. E. Waligóra, Kraków, s. 39-46.

Dembińska Maria 1985. Pożywienie postne i pokutne mnichów we wczesnym średniowieczu (V-XI w.), „Kwartalnik Historii Kultury Materialnej”, R. XXXIII, nr 4, s. 367-381.

Dochody i wydatki. 2002-2004. Dochody $i$ wydatki Konwentu Braci Eremitów św. Augustyna przy kościele św. Katarzyny w Kazimierzu. Ze zbiorów Archiwum Państwowego w Krakowie, t. 1: 1502-1505, t. 2: 1506-1508, wyd. K. Jelonek-Litewka i in., Kraków.

Dumanowski Jarosław. 2014. Wiedza, narracja i smak. Staropolskie ksiązki kucharskie i porady kulinarne jako źródło historyczne, „Kwartalnik Historii Kultury Materialnej”, R. LXII, nr 4, s. 527-540.

Gąsiorowska Patrycja. 2010. Kuchnia i infirmeria w klasztorze klarysek krakowskich do końca XVIII wieku, [w:] Sanctimoniales. Zakony żeńskie w Polsce i Europie Środkowej (do przełomu XVIII i XIX wieku), red. D. Karczewski, A. Radzimiński, Z. Zyglewski, Bydgoszcz-Torun, s. 394-406.

\footnotetext{
91 Rajman J. 2010, s. 209.

92 Kucharz doskonały. 2012, s. 17.
} 
Gronowski Tomasz Michał. 2007. Zwyczajny klasztor, zwyczajni mnisi. Wspólnota tyniecka w średniowieczu, Kraków.

Gustaw Romuald, Sitnik Aleksander Krzysztof. 2013. Kościót i klasztor św. Józefa SS. Bernardynek w Krakowie 1646-2009, wyd. II, Kalwaria Zebrzydowska.

Klonder Andrzej. 2018. Piwo, wódka i inni konkurencji wina w Polsce nowożytnej, [w:] Wino i historia, red. D. Dias-Lewandowska, G. Kurczewski, Studia z historii wina w Polsce, t. II, Warszawa, s. $20-40$.

Kracik Jan. 1985. Post po staropolsku, „Nasza Przeszłość”, t. 75, s. 65-90.

Kramarska-Anyszek Krystyna. 1977. Dzieje klasztoru PP. Norbertanek w Krakowie na Zwierzyńcu do roku 1840, „Nasza Przeszłość”, t. 47, s. 5-169.

Księga szafarska. 2013. Księga szafarska dworu Jana III Sobieskiego 1695-1696, oprac. J. Dumanowski, M. Próba, Ł. Truściński, Monumenta Poloniae Culinaria, t. IV, Warszawa.

Kucharz doskonały. 2012. Kucharz doskonały pożyteczny dla zatrudniajacych się gospodarstwem, wyd. i oprac. J. Dumanowski, współudz. A. Kleśta-Nawrocka, Monumenta Poloniae Culinaria, t. III, Warszawa.

Przybyłowicz Olga Miriam. 2011. Rachunki klasztorne jako źródło do poznania realiów życia klasztornego. Najstarsza księga rachunkowa klarysek ze Starego Sacza, [w:] Realia życia codziennego w Europie Środkowej ze szczególnym uwzględnieniem Śląska, red. A. Barciak, Katowice-Zabrze, s. 107-130.

Przybyłowicz Olga Miriam. 2013. Jak panny zakonne rozliczały się? Księgi rachunkowe jako źródło do badań nad polskimi klasztorami żeńskimi w XVI-XVIII w., [w:] Klasztor w gospodarce średniowiecznej i nowożytnej, red. M. Derwich, Wrocław, s. 101-114.

Przybyłowicz Olga Miriam. 2019. Źródła rękopiśmienne z klasztoru klarysek gnieźnieńskich w Archiwum Archidiecezjalnym w Gnieźnie. Stan wiedzy, prezentacja zachowanej spuścizny i możliwości badawcze, „Archiwa, Biblioteki i Muzea Kościelne”, t. 112, s. 317-336, https:// doi.org/10.31743/abmk.2019.112.16 (dostęp 30.05.2021).

Rajman Jerzy. 2001. O źródłach do zagadnienia positków i napojów w klasztorze średniowiecznym, „Studia Historyczne”, t. 44, nr 2, s. 183-198.

Rajman Jerzy. 2010. Jadtospis norbertanek zwierzynieckich z XVIII wieku, [w:] Sanctimoniales. Zakony żeńskie w Polsce i Europie Środkowej (do przełomu XVIII i XIX wieku), red. D. Karczewski, A. Radzimiński, Z. Zyglewski, Bydgoszcz-Toruń, s. 407-411.

Staropolskie przepisy. 2017. Staropolskie przepisy kulinarne. Receptury rozproszone z XVI-XVIII w. Źódła rękopiśmienne, red. J. Dumanowski, t. VII, Warszawa.

Szylar Anna. 2004. Kuchnia benedyktynek sandomierskich, „Zeszyty Sandomierskie”, nr 22, s. 32-38.

Szylar Anna. 2005. Rzecz o tym, jak benedyktynki kuchnię prowadziły..., „Nasza Przeszłość”, t. 103, s. $189-224$.

Szylar Anna. 2013. „, Sprawa o tym, jak benedyktynki gospodarstwo prowadzity”. Organizacja i funkcjonowanie gospodarki benedyktynek w Sandomierzu w XVII i XVIII w., [w:] Klasztor w gospodarce średniowiecznej i nowożytnej, red. M. Derwich, Wrocław, s. 447-460.

Więcławski Bogusław. 1989. Zaopatrzenie i konsumpcja w Poznaniu w drugiej połowie XVIII wieku, Warszawa-Poznań.

Wyrwa Andrzej Marek. 2004. W kuchni i przy stole „, szarych mnichów”, czyli o wyżywieniu cystersów w świetle źródel normatywnych zakonu oraz wybranych źródet pisanych, archeologicznych i przyrodniczych, [w:] Materiały z VII Sesji Naukowej Uniwersyteckiego Centrum Archeologii Sredniowiecza i Nowożytności ,, Wyposażenie wnętrz w średniowieczu”, Toruń, 21-22 listopada 2002 roku, red. J. Olczak, Archaelogia Historica Polona, t. 14, Toruń, s. 51-113.

"Baked stuffed lamb, beetroot, and a piece of sweet bread." Festive dinners of the Kraków Bernardine Nuns in the second half of the 18 th century

This article refers to the research trend that is developing dynamically in Poland and abroad: studies on culinary culture. The presented findings are pioneering in the literature on the subject 
published to date because of the community which they concern - the cloistered convent of Bernardine nuns in Krakow - and the source base taken into account in the research paper. The basis for consideration is the oldest account book of the convent from the years 1762-1766. Its uniqueness lies not only in the separation of more than 10 categories of expenses, including food, but above all in the content of the last 15 pages. It contains information on the one-year daily menu, mainly on dinners (suppers are mentioned much less frequently), of the Sisters of the Third Order Regular of St. Francis. This part of the manuscript is entitled: "On 8 November 1765, on the octave of All Saints since the election, all dinners are laid down here for the memory of the understanding of the expenses." The records were kept by the hand of one of the sisters (as evidenced by the feminine form of the first person predicate) for a year, until 15 November 1766.

This article discusses the meals served to the Bernardines on feast days, i.e. on Sundays, and the most important festivals in the Church calendar, including the feasts of the Franciscan Order. Dinners on these days were characterised not only by the variety of dishes prepared but also by their larger number (usually more than four) compared to those eaten on weekdays. Of course, church fasts were observed, and meat was served to healthy nuns only on days exempt from the ban on eating it. For example, the menu for the festive Sunday on 10 November 1765 includes chicken broth, a quarter each of hen and roast goose with apples, veal in a yellow sauce with noodles, brisket roast with limes and olives, cabbage with pork and stuffed bulsztuk in almond sauce; wine was drunk and vodka was served "to the refectory" for all the nuns. In contrast, on the first Sunday of the Advent fast (17 November that year) the following dishes were served: "grey soup" with fine groats, crucian carp in grey sauce, millet groats, and vegetables.

The most sumptuous and lavish dinners, with more than five courses, were prepared for the Bernardine Sisters at Christmas and Easter. The record number of meals was noted on 26 December - eight main courses (not counting sweets (gingerbread and strudel)) and alcohol (vodka and wine) for the sisters and their confessor.

Among fish, the most exquisite dish, served mainly on the most important church feasts, was pike, cooked "in yellow or white sauce or with sauce and almonds" (recorded a total of 18 times in the analysed period). As far as meats are concerned, veal was the most popular (served 13 times), including in the form of roast (7 times) and leg of veal (twice). As far as poultry is concerned, hens were most frequently eaten — in broth ( 8 times), followed by geese - served with apples (5 times). Both fish and meat were served with sauces: yellow (17 times, once with wine and cinnamon), white (16 times), grey (4 times), black (1 time), and almond (1 time). Among flour products, which were an indispensable part of the nuns' menu, groats were consumed most often ( 22 times). The most common soups eaten by the Bernardines were broth (13 times), on fast days potage (4 times) and "grey soup" (1 time). A wide variety of vegetables were also served, while fruit was added to meat (apples and plums, limes and lemons) and sweets (gooseberries). Gingerbread was also a delicacy (most often mentioned in the source, i.e. 18 times, and once described as "small gingerbreads"), as well as kołacze (sweet breads), strudels, olive oil cake, and a cake described as "three-groschen."

In summary, the sisters ate quite varied meals, and there were many dishes even on fast days. In accordance with the culinary trends of the era, dishes did not contain the sharp spices and flavour contrasts that dominated Polish cuisine in the 17th century. The set of consumed dishes places this Kraków community among the higher social strata of the Polish-Lithuanian Commonwealth in the 18th century.

Translated by Karolina Płoska

Proofread by 